УДК 615.074+615.322:58

DOI https://doi.org/10.11603/2312-0967.2018.4.9692

\title{
ВИВЧЕННЯ ГЕПАТОПРОТЕКТОРНОї ДІЇ ЕКСТРАКТІВ ІЗ ПЛОДІВ СЛИВИ дОМАШНЬОї
}

\author{
(c) I. В. Сенюк, Башар Джабар Аль Сахлані, Мохаммед Шахм Басім \\ Національний фрармацевтичний університет, Харків \\ citochrom@gmail.com
}

\begin{abstract}
Мета роботи. Вивчення гепатопротекторної активності сухих екстрактів із плодів сливи, яку оцінювали за активністю гепатоспецифічних фрерментів у сироватці крові, а також за впливом на показники білкового обміну, зокрема на рівень сечовини та загального білка у крові тварин.

Матеріали і методи. Алкогольний гепатит викликали через внутрішньошлункове введення $40 \%$ етанолу в дозі 7 мл/кг протягом 7 днів. Сухі екстракти з плодів сливи вводили внутрішньошлунково у дозах 100 та 200 мг/кг. Спектрофотометрично визначали активність амінотрансфераз, лужної фоссфатази, у-глутамілтранспептидази, рівень сечовини та загального білка.

Результати й обговорення. Розвиток експериментального алкогольного гепатиту супроводжувався цитолітичним синдромом та ураженням гепатобіліарної системи. У крові збільшувався рівень сечовини та зменшувався рівень загального білка. Сухі екстракти достовірно знижували активність гепатоспецифічних ферментів, нормалізували рівень сечовини та загального білка лише у дозі 200 мг/кг. Високу ефективність проявив сухий екстракт, що містив волокна, він наближався до препарату порівняння «Силібору». Зниження активності лужної фросфратази при введенні сухих екстрактів, що містили волокна, свідчило про нормалізацію секреторної функції печінки в щурів що, зумовлено посиленням екскреції жовчі.

Висновки. Сухі екстракти, що містили волокна та полісахаридні комплекси, продемонстрували виразний гепатопротекторний ефект. Максимальна гепатопротекторна активність спостерігалася для сухого екстракту, який містив волокна у дозі 200 мг/кг.
\end{abstract}

Ключові слова: плоди сливи; сухий екстракт із волокнами; послаблювальна активність; печінка.

Вступ. Закрепи, або утруднену або систематично недостатню десекацію, за даними медичної статистики, діагностують у 15 \% населення земної кулі [1]. Тривалі закрепи можуть спричинити ускладнення, запалення сигмоподібної і прямої кишки [2], хвороби прямої кишки, зокрема геморой [3].

На сьогодні на фрармацевтичному ринку України присутній широкий спектр послаблювальних препаратів синтетичного та рослинного походження. Проте використання послаблювальних препаратів досить швидко призводить до звикання [4], тому пошук та розробка нових препаратів із послаблювальною активність $€$ на даний час актуальною проблемою. Перевага рослинних препаратів над синтетичними полягає у тому, що рослинні препарати, які містять різні біологічно активні речовини з широким спектром дії, можуть проявляти позитивну дію на організм [5].

Плоди сливи домашньої (лат. Prunus domestica), сімейства Rosaceae, $€$ джерелом поліфенольних сполук із широким спектром дії. Екстракт із плодів сливи знижує вміст холестеролу в крові [6], пригнічує розвиток пухлин прямої кишки шляхом пригнічення фоссрорилювання та експресії протеїнкінази B/Akt [7]. Наявні дані щодо ефективності застосування екс- трактів сливи для запобігання та терапії раку печінки [8]. Флавоноїди, які містяться у сливі, можна використовувати для лікування гепатиту C [9]. Раніше ми встановили, що сухі екстракти з плодів сливи, які містять волокна та полісахаридні комплекси, проявляють виразну послаблювальну дію [10]. Встановлено антиоксидантну активність даних екстрактів [11]. Проте дані щодо гепатопротекторної дії екстрактів із плодів сливи відсутні.

Мета роботи - вивчення гепатопротекторної активності сухих екстрактів із плодів сливи, зокрема вплив сухих екстрактів на активність гепатоспецифрічних фрерментів у сироватці крові, а також на показники білкового обміну, який оцінювали за рівнем сечовини та загального білка в крові тварин.

Матеріали і методи. Дослідження проводили на 110 аутбредних самицях щурів масою 220-250 г відповідно до «Загальних етичних принципів експериментів на тваринах», (Україна, 2001), що погоджені 3 «Європейською конвенцією про захист хребетних тварин, що використовуються для експериментальних та інших наукових цілей» (Страсбург, 1985) та Етичним кодексом Всесвітньої медичної асоціації (Гельсінська декларація, 1964).

ISSN 2312-0967. Pharmaceutical review. 2018. № 4 
Фармакологічні дослідження біологічно активних речовин Pharmacological researches of biologically active substances

Алкогольний гепатит викликали через внутрішньошлункове введення $40 \%$ етанолу у дозі 7 мл/кг протягом 7 днів [12]. Сухі екстракти з плодів сливи, які містили волокна (СЕВ) та полісахаридні комплекси (СЕПК), вводили внутрішньошлунково у дозах 100 або 200 мг/кг. Стандартизацію проводили за вмістом нейтральних цукрів на кафедрі хімії природних сполук НФаУ. Як препарат порівняння використовували гепатопротектор рослинного походження - силібор (ФК «Здоров'я», Україна ) у дозі 25 мг/кг. Всі препарати розчиняли або суспендували у 4 мл очищеної води та вводили внутрішньошлунково через годину після надходження розчину етанолу, тваринам контрольної групи та контрольної патології вводили лише очищену воду для відтворення рівних умов експерименту.

Тварин декапітували та збирали кров для отримання сироватки. У сироватці крові визначали рівень сечовини та загального білка за допомогою стандартних наборів реактивів ТОВ НВП «Філісіт-Діагностика» (Україна). Стан печінки та жовчосекреторної функції печінки оцінювали за активністю ферментів аланінамінотрансорерази (АлАТ), аспартатамінотрансорерази (АсАт), лужної фроссратази (ЛФ) та у-глутамілтранспептидази (У-ГТ). Активність фрерментів визначали за допомогою стандартних наборів реактивів ТОВ НВП «Філісіт-Діагностика» (Україна).

Статистичну обробку отриманих даних проводили за допомогою програми STATISTICA (StatSoftlnc., США, версія 6.0).

Результати й обговорення. Розвиток експериментального алкогольного гепатиту супроводжувався розвитком цитолітичного синдрому, що опосередковується через підвищення рівня амінотрансфрераз та ураженням гепатоцитів, яке відображалось у підвищенні активності ЛФ (табл. 1). Підвищення активності у-ГТ за умов модельної патології $€$ не стільки маркером ушкодження клітин печінки, а перш за все, зумовлене збільшенням її синтезу клітинами печінки внаслідок регулярного введення алкоголю тваринам (див. табл. 1). Досліджувані сухі екстракти достовірно знижували активність гепатоспецифічних фрерментів лише у дозі 200 мг/кг маси тварин. При цьому екстракт СЕПК знижував активність АлАТ, АсАТ та ЛФ на 18,0, 19,3 та 10 \% відповідно (див. табл. 1). Водночас екстракт СЕВ знижував активність АлАТ, АсАТ та ЛФ на 28,8, 30,1 та 31,2 \%, відповідно (див. табл. 1). Таким чином, більшу ефективність проявив сухий екстракт, що містив волокна, і за своєю ефективністю він наближався до препарату порівняння силібору (табл. 1). Зниження активності свідчить про відновлення цілісності плазматичних мембран гепатоцитів, що може бути зумовлене гальмуванням процесів перекисного окиснення ліпідів, яке посилюється при введенні етанолу [11]. Зниження активності ЛФ у разі введення СЕВ свідчить про нормалізацію роботи гепатоцитів печінки в щурів. Гепатопротректорна дія екстракту, що містить волокна, ймовірно пов'язана 3 наявністю у його складі комбінації поліфенольних сполук, які на сьогодні детально вивчаються на кафедрі хімії природних сполук НФаУ. Отримані дані узгоджуються з даними літератури [13] про те, що екстракти $з$ плодів сливи можуть посилювати екскрецію жовчі, а волокна, які входять до складу цих екстрактів, незворотно зв'язують холестерол. Зазначений механізм є ключовим у гіпохолестеролемічній дії екстрактів сливи, оскільки з жовчю посилюється виведення холестеролу з організму, а печінка поглинає надлишковий холестерол із крові та використовує його на біосинтез жовчних кислот [6].

Для діагностики фрункціонального стану печінки велике значення має визначення показників білкового обміну, зокрема загального рівня білка в сироватці, а

Таблиця 1. Вплив сухого екстракту із плодів сливи на активність гепатоспецифічних ферментів у сироватці крові на тлі алкогольного гепатиту $(\mathrm{M} \pm \mathrm{m}, \mathrm{n}=10)$

\begin{tabular}{|c|c|c|c|c|}
\hline Експериментальна група & АлАТ, мккат/л & АсАТ, мккат/л & ЛФ, мккат/л & у-ГТ, мккат/л \\
\hline Контрольна група & $0,56 \pm 0,10$ & $1,41 \pm 0,12$ & $3,68 \pm 0,21$ & $2,56 \pm 0,19$ \\
\hline Контрольна патологія (КП) & $1,17 \pm 0,15^{\star}$ & $2,54 \pm 0,26^{*}$ & $6,21 \pm 0,39 *$ & $5,97 \pm 0,42^{\star}$ \\
\hline КП+Силібор 25 мг/кг & $0,85 \pm 0,09 * / * \star$ & $1,93 \pm 0,14^{\star / \star *}$ & $5,08 \pm 0,18^{\star / \star *}$ & $4,93 \pm 0,24^{\star / * *}$ \\
\hline КП+СЕВ 100 мг/Кг & $0,94 \pm 0,12^{*}$ & $2,11 \pm 0,30 *$ & $5,59 \pm 0,35^{\star}$ & $5,28 \pm 0,35^{\star}$ \\
\hline КП+СЕВ 200 мг/кг & $0,82 \pm 0,08^{\star / \star \star}$ & $1,80 \pm 0,09^{\star / \star \star}$ & $4,31 \pm 0,16^{\star / \star \star}$ & $4,25 \pm 0,26^{\star / \star *}$ \\
\hline КП+СЕПК 100 мг/Кг & $1,15 \pm 0,09 *$ & $2,48 \pm 0,15^{\star}$ & $6,14 \pm 0,29 *$ & $5,83 \pm 0,37^{\star}$ \\
\hline КП+СЕПК 200 мг/Кг & $0,96 \pm 0,07^{\star / \star \star}$ & $2,05 \pm 0,15^{\star / \star \star}$ & $5,61 \pm 0,18^{\star / * \star}$ & $5,30 \pm 0,30 *$ \\
\hline CEB $100 \mathrm{мг/кг}$ & $0,56 \pm 0,03$ & $1,41 \pm 0,12$ & $3,68 \pm 0,17$ & $2,56 \pm 0,12$ \\
\hline CEB $200 \mathrm{Mг} / \mathrm{Kг}$ & $0,62 \pm 0,09$ & $1,35 \pm 0,11$ & $3,05 \pm 0,23$ & $2,49 \pm 0,15$ \\
\hline СЕПК 100 мг/Кг & $0,59 \pm 0,06$ & $1,52 \pm 0,14$ & $3,42 \pm 0,28$ & $2,31 \pm 0,16$ \\
\hline СЕПК 200 мг/КГ & $0,68 \pm 0,07$ & $1,29 \pm 0,09$ & $3,53 \pm 0,19$ & $2,68 \pm 0,13$ \\
\hline
\end{tabular}

Примітки: * - відмінності вірогідні відносно контрольної групи ( $\mathrm{s} \leq 0,05)$;

** - відмінності вірогідні відносно контрольної патології $(p \leq 0,05)$.

ISSN 2312-0967. Фармацевтичний часопис. 2018. № 4 
Фармакологічні дослідження біологічно активних речовин Pharmacological researches of biologically active substances

також вміст кінцевого продукту обміну білків - сечовини. Отримані дані представлено в таблиці 2. Розвиток алкогольного ураження печінки супроводжувався достовірним, майже у 2 рази, підвищенням вмісту сечовини, що свідчить про посилення катаболічних процесів, пов'язаних із загальною токсичною дією етанолу на організм. Досліджувані сухі екстракти достовірно знижували вміст сечовини лише у дозі 200 мг/кг маси тварин. При цьому більшу активність виявив сухий екстракт, який містив волокна та відповідно знижував досліджуваний показник на 29 \% і за ефективністю наближався до препарату порівняння «Силібору». Отримані результати можуть бути пов'язані з пригніченням токсичної дії етанолу на організм у цілому, що опосередковується через анти- оксидантні властивості біофрлавоноїдів (антоціанів) досліджуваних екстрактів [14].

У тварин з експериментальним ураженням печінки також спостерігали зниження рівня загального білка в сироватці крові (див. табл. 2). Введення СЕПК в обох досліджуваних дозах не впливало на цей показник. Введення СЕВ достовірно підвищувало рівень загального білка лише в дозі 200 мг/кг, ймовірно за наявності у складі досліджуваного екстракту протеїногених амінокислот. Проте слід зазначити, що описані зміни відбувалися у межах фрізіологічно-нормальних показників та при експериментальних умовах клітини печінки не зазнали глибоких уражень білоксинтезуючої системи, і обрана модель експерименту відповідає поставленій меті.

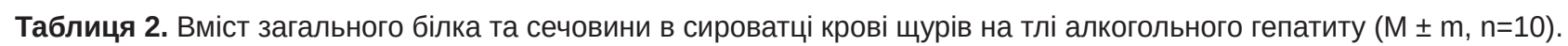

\begin{tabular}{|c|c|c|}
\hline Експериментальна група & Загальний білок, г/л & Сечовина, ммоль/л \\
\hline Контрольна група & $69,31 \pm 1,06$ & $6,28 \pm 0,41$ \\
\hline Контрольна патологія (КП) & $61,75 \pm 1,64^{*}$ & $11,02 \pm 0,64^{*}$ \\
\hline КП+Силібор 25 мг/кг & $65,95 \pm 0,93^{\star / * *}$ & $8,11 \pm 0,33^{\star / * \star}$ \\
\hline КП+СЕВ 100 мг/Кг & $60,38 \pm 1,40^{*}$ & $10,32 \pm 0,59^{*}$ \\
\hline КП+CEВ 200 мг/Кг & $66,07 \pm 0,72^{\star / * \star}$ & $8,52 \pm 0,41^{\star / \star \star}$ \\
\hline КП+СЕПК 100 мг/Кг & $59,89 \pm 2,65^{*}$ & $10,87 \pm 0,77^{\star}$ \\
\hline КП+СЕПК 200 мг/Кг & $63,31 \pm 2,51^{*}$ & $9,40 \pm 0,28^{\star / \star \star}$ \\
\hline CEB 100 мг/кг & $68,64 \pm 2,26$ & $6,42 \pm 0,62$ \\
\hline CEB $200 \mathrm{мг/кг}$ & $67,95 \pm 1,87$ & $6,87 \pm 0,53$ \\
\hline СЕПК 100 мг/КГ & $70,03 \pm 2,14$ & $6,03 \pm 0,71$ \\
\hline СЕПК 200 мг/кг & $69,44 \pm 1,09$ & $6,56 \pm 0,38$ \\
\hline
\end{tabular}

Примітки: * - відмінності вірогідні відносно контрольної групи ( $\mathrm{s} \leq 0,05)$;

** - відмінності вірогідні відносно контрольної патології $(p \leq 0,05)$.

Висновки. Розвиток контрольної патології супроводжувався ушкодженням мембран клітин печінки, порушенням функціонування гепатобіліарної системи та посиленням катаболічних процесів. Сухі екстракти, що містили волокна та полісахаридні комплекси, продемонстрували виразний гепатопротекторний ефект, який був доведений зниженням активності гепатоспецифічних ферментів та як наслідок стабілізацією функціонування гепатоцитів печінки.
Також досліджувані екстракти проявляли нормалізуючу дію на катаболічні процеси за умов алкогольної інтоксикації.

Максимальну гепатопротекторну активність спостерігали для сухого екстракту, що містить волокна у дозі 200 мг/кг. Сухий екстракт, який містить полісахаридні комплекси у дозі 200 мг/кг, продемонстрував гепатопротекторну активність, проте не мав виразного впливу на функціональний стан печінки.

\title{
ИЗУЧЕНИЕ ГЕПАТОПРОТЕКТОРНОГО ДЕЙСТВИЯ ЭКСТРАКТОВ ИЗ ПЛОДОВ СЛИВЫ ДОМАШНЕЙ
}

\author{
И. В. Сенюк, Башар Джабар Аль Сахлани, Мохаммед Шахм Басим \\ Национальный фрармацевтический университет, Харьков \\ citochrom@gmail.com
}

Цель работы. Изучение гепатопротекторной активности сухих экстрактов из плодов сливы, которую оценивали по активности гепатоспецифических фрерментов в сыворотке крови, а также на показатели белкового обмена, в частности на уровень мочевины и общего белка в крови животных.

ISSN 2312-0967. Pharmaceutical review. 2018. № 4 
Фармакологічні дослідження біологічно активних речовин

Pharmacological researches of biologically active substances

Материалы и методы. Алкогольный гепатит вызвали через внутрижелудочное введение 40 \% этанола в дозе 7 мл/кг в течение 7 дней. Сухие экстракты из плодов сливы вводили внутрижелудочно в дозе 100 или 200 мг/кг. Активность аминотрансорераз, щелочной фросфатазы (ЩФ), у-глутамилтранспептидазы, уровень мочевины и общего белка определяли спектрофотометрически.

Результаты и обсуждение. Развитие экспериментального алкогольного гепатита сопровождалось фрормированием цитолитического синдрома и поражением желчевыделительной системы. В крови увеличивался уровень мочевины и уменьшалось содержание общего белка. Сухие экстракты в дозе 200 мг/кг массы животных достоверно снижали активность гепатоспецифических фрерментов, нормализовали уровень мочевины и общего белка. Большую эфрфективность проявил сухой экстракт, содержащий волокна, и по своей эффеективности он приближался к препарату сравнения «Силибору». Снижение активности щФ при введении сухих экстрактов, содержащих волокна, свидетельствует о стабилизации фруционального состояния печени у крыс, что вероятно связанно с содержанием в нем комплекса полифенольных соединений.

Выводы. Сухие экстракты, содержащие волокна и полисахаридные комплексы, продемонстрировали выраженный гепатопротекторный эффект. Максимальная гепатопротекторная активность наблюдалась для сухого экстракта, содержащего волокна в дозе 200 мг/кг.

Ключевые слова: плоды сливы; сухой экстракт с волокнами; слабительная активность; печень.

\section{STUDY OF HEPATOPROTECTIVE ACTION OF EXTRACTS FROM GARDEN PLUM FRUIT}

\section{V. Senjuk, Bashar Jabar AI Sahlani, Mohammed Shahm Basim}

National University of Pharmacy, Kharkiv

citochrom@gmail.com

The aim of the work. Studying the hepatoprotective activity of garden plum fruit dry extracts with fibers and polysaccharide complexes, which was evaluated by the activity of hepatospecific enzymes in serum, as well as on the parameters of protein metabolism, urea and total protein levels in blood of rats.

Materials and Methods. Alcoholic hepatitis was induced in rats by intragastric administration of $40 \%$ ethanol at a dose of $7 \mathrm{ml} / \mathrm{kg}$ for 7 days. Plum fruit dry extracts were administered intragastrically at doses of 100 or $200 \mathrm{mg} / \mathrm{kg}$. Aminotransferases, alkaline phosphatase (AP), y-glutamyltranspeptidase activity, urea and total protein level were determined spectrophotometrically.

Results and Discussion. Experimental alcoholic hepatitis development was accompanied by a cytolytic syndrome and a hepatobiliary lesion. The urea level increased and total protein level decreased in blood. Dry extracts significantly lowered hepatospecific enzymes activity in blood serum, normalized urea and total protein levels at a dose of $200 \mathrm{mg} / \mathrm{kg}$. We found that dry extract with fibers was the most active, and its effect was comparable to the reference drug Silibor. Alkaline phosphatase activity reduction due to dry extracts with fibers administration indicated the stabilization of the functional state of the liver in rats, which is probably due to the content of the complex of polyphenolic compounds in it.

Conclusions. Significant hepatoprotective effect for dry extracts with fibers and polysaccharide complexes was showed. The dry extract with fibers was the most effective at a dose of $200 \mathrm{mg} / \mathrm{kg}$.

Key words: plum fruit, dry extract with fibers; laxative activity; liver.

\section{Список літератури}

1. Randomised clinical trial: mixed soluble/insoluble fibre vs. psyllium for chronic constipation / A. Erdogan, S. S. Rao, D. Thiruvaiyaru [et al.] // Aliment. Pharmacol. Ther. - 2016. - No. 1. - P. 35-44. doi: 10.1111/apt.13647.

2. New ultrasonographic evaluation of stool and/or gas distribution for treatment of chronic constipation / N. Manabe, T. Kamada, J. Hata [et al.] // Int. J. Colorectal Dis. -2018. - No. 3. - P. 345-348. DOI: 10.1007/s00384-018-2964-3

3. Gupta S. Operculina turpethum (Linn.) Silva Manso as a medicinal plant species: a review on bioactive components and pharmacological properties / S. Gupta, A. Ved // Pharmacogn. Rev. - 2017. - No. 22. - P. 158-166. doi: 10.4103/ phrev.phrev_6_17
4. Скрипник І. М. Вибір медикаментозного засобу для лікування обстипаційного синдрому при виразковій хворобі в поєднанні з синдромом подразненого кишечнику / І. М. Скрипник // Сучасна гастроентерологія. - 2006. T. 30, № 4. - C. 85-89.

5. Гарник Т. П. Сучасні технології виробництва фрітозасобів та перспективи фрітотерапії / Т. П. Гарник // Фітотерапія. Часопис. - 2008. - № 1. - С. 59-63.

6. Siddiqui R. A. Plums as potential dietary agents to prevent obesity and obesity-related disorders / R. A. Siddiqui // J. Obes. Ther. - 2017. - No. 1(1). - Mode access: https:// www.scitechnol.com/peer-review/plums-as-potential-dietary-agents-to-prevent-obesity-and-obesityrelated-disor-

ISSN 2312-0967. Фармацевтичний часопис. 2018. № 4 
ders-x4TO.php?article id $=6545 \# 19$

7. Plum polyphenols inhibit colorectal aberrant crypt foci formation in rats: potential role of the miR-143/protein kinase B/mammalian target of rapamycin axis / N. Banerjee, H. Kim, S. T. [et al.] // Talcott Nutr. Res. - 2016. - No. 10. P. 1105-1113. doi: 10.1016/j.nutres.2016.06.008.

8. Dietary natural products for prevention and treatment of liver cancer / Y. Zhou, Y. Li, T. Zhou [et al.] // Nutrients. 2016. - No. 3. - P. 156. doi: 10.3390/nu8030156.

9. Identification of a flavonoid isolated from plum (Prunus domestica) as a potent inhibitor of hepatitis C virus entry / M. Bose, M. Kamra, R. Mullick [et al.] // Sci. Rep. - 2017. 1. - P. 3965. doi:10.1038/s41598-017-04358-5.

10. Сенюк І. В. Вивчення послаблюючої активності різних субстанцій, одержаних з плодів Сливи домашньої Prunus domestica / І. В. Сенюк, Башар Джабар Алі АльСахлані, Л. В. Упир // Український біофармацевтичний журнал. - 2017. - № 5 (52). - С. 21-25.

\section{References}

1. Erdogan A, Rao SS, Thiruvaiyaru D, Lee YY, Coss Adame E, et al. Randomised clinical trial: mixed soluble/ insoluble fibre vs. psyllium for chronic constipation. Aliment Pharmacol Ther. 2016;44(1): 35-44. doi: 10.1111/apt.13647. 2. Manabe N, Kamada T, Hata J, Haruma K. New ultrasonographic evaluation of stool and/or gas distribution for treatment of chronic constipation. Int J Colorectal Dis. 2018;33(3): 345-8. doi: 10.1007/s00384-018-2964-3.

3. Gupta S, Ved A. Operculina turpethum (Linn.) Silva Manso as a medicinal plant species: a review on bioactive components and pharmacological properties. Pharmacogn Rev. 2017;11(22): 158-66. doi: 10.4103/phrev.phrev_6_17. 4. Skrypnyk IM. [Choice of a medicament for the treatment of obstipation syndrome in peptic ulcer in combination with irritable bowel syndrome]. Such. Hastroent.;2006;4(30): 85-9.

5. Garnik TP. [Modern technologies of phyto-drug production and phytotherapy perspectives]. Fitoterap. Chasop. 2008;1: 59-63.

6. Siddiqui RA. Plums as potential dietary agents to prevent obesity and obesity-related disorders. J Obes Ther. 1(1). Available at: www.scitechnol.com/peer-review/plumsas-potential-dietary-agents-to-prevent-obesity-and-obesityrelated-disorders- $\times 4$ TO. php?article_id=6545\#19

7. Banerjee N, Kim H, Talcott ST, Turner ND, Byrne DH, Mertens-Talcott SU. Plum polyphenols inhibit colorectal aberrant crypt foci formation in rats: potential role of the miR-143/protein kinase B/mammalian target of rapamycin axis. Nutr Res. 2016;36(10): 1105-13. doi: 10.1016/j.nutres.2016.06.008.
11. Amhal N. E. Investigation of the plum fruit dry extracts antioxidant effect / N. E. Amhal // Topical issues of new drugs development: Abstracts of XXIV International Scientific And Practical Conference Of Young Scientists And Student (April 20, 2017) in 2 vol., Vol. 2. - Kharkiv: Publishing Office NUPh, 2017. - Р. 214-215.

12. Доклинические исследования лекарственных средств : метод. рек. / под ред. А. В. Стефранова. - К. : Авиценна, 2002. - 528 с.

13. Stacewicz-Sapuntzakis M. Dried plums and their products: composition and health effects-an updated review / M. Stacewicz-Sapuntzakis // Crit. Rev. Food Sci. Nutr. - 2013. No. 53. - P. 1277-1302. doi: 10.1080/10408398.2011.563880. 14. Morabbi Najafabad A. Free radical scavenging capacity and antioxidant activity of methanolic and ethanolic extracts of plum (Prunus domestica L.) in both fresh and dried samples / A. Morabbi Najafabad, R. Jamei // Avicenna J. Phytomed. - 2014. - No. 4(5). - P. 343-353.

8. Zhou Y, Li Y, Zhou T, Zheng J, Li S, Li HB. Dietary natural products for prevention and treatment of liver cancer. Nutrients. 2016;8(3): 156. doi: 10.3390/nu8030156.

9. Bose M, Kamra M, Mullick R, Bhattacharya S, Das S, Karande AA. Identification of a flavonoid isolated from plum (Prunus domestica) as a potent inhibitor of Hepatitis $C$ virus entry. Sci Rep. 2017;7(1): 3965. doi: 10.1038/s41598-01704358-5.

10. Seniuk I, Bashar Jabar Al-Sahlani, Lenchyk L. [Investigation of different substances catharic properties made from Prunus domestica]. Ukrainskyi biofarmatsevt nurn. 2017;5(52): 21-5. Ukrainian.

11. Amhal NE. Investigation of the plum fruit dry extracts antioxidant effect Topical issues of new drugs development: Abstracts of XXIV International Scientific and Practical Conference of Young Scientists and Student (April 20, 2017) in 2 vol., Vol. 2. Kharkiv: Publishing Office NUPh; 2017. Ukrainian.

12. Stefanov AV. Ed. Preclinical research of drugs: method. rec. [Доклинические исследования лекарственных средств : метод. рек.] Kyiv: Avicenna; 2002. Russian.

13. Stacewicz-Sapuntzakis M. Dried plums and their products: composition and health effects-an updated review. Crit Rev Food Sci Nutr. 2013;53(12): 1277-302. doi: 10.1080/10408398.2011.563880.

14. Morabbi Najafabad A, Jamei R. Free radical scavenging capacity and antioxidant activity of methanolic and ethanolic extracts of plum (Prunus domestica L.) in both fresh and dried samples. Avicenna J Phytomed. 2014;4(5): 34353. 